\title{
A Dose-Response Meta-Analysis on the Association Between Alcohol Consumption and Incidence of Atrial Fibrillation
}

\section{Haifu Zhang}

Hangzhou Normal University Affiliated Hospital

\section{Qinxia Zhang}

Hangzhou Normal University

\section{Dong Yang}

Hangzhou Normal University Affiliated Hospital

Zhao Xu

Hangzhou Normal University Affiliated Hospital

Xingwei Zhang ( $\nabla$ xwzhang@hznu.edu.cn )

Hangzhou Normal University Affiliated Hospital

Research article

Keywords: Atrial fibrillation, Alcohol consumption

Posted Date: October 14th, 2020

DOI: https://doi.org/10.21203/rs.3.rs-89496/v1

License: () (i) This work is licensed under a Creative Commons Attribution 4.0 International License. Read Full License 


\section{Abstract}

Background: Atrial fibrillation (AF) is one of the most common arrhythmias in clinical practice. Alcohol consumption has been linked to the occurrence of AF.

Methods: A comprehensive search of electronic databases (PubMed, Cochrane Library, OVID, Google scholar, and Web of Science) was performed. The search yielded a total of 1177 articles, and 12 cohort studies from the total were included in the meta-analysis. The effects of different doses of alcohol consumption on the risk of AF in men and women were compared using hierarchical analysis. Dose-response curves of alcohol consumption and risk of AF were plotted for the two groups according to sex.

Results: The risk of AF increased with increased alcohol consumption in both men and women. In the male population, lightmoderate alcohol consumption did not increase the risk of AF (HR: 1.07, 95\% Cl: 0.92-1.23, P=0.38), while heavy alcohol consumption significantly increased the risk of AF (HR: 1.38, 95\% Cl: 1.23-1.54, $\mathrm{P}<0.01$ ). In the female population, the risk of $A F$ was not significantly increased by either light-moderate or heavy alcohol consumption (light- moderate drink: HR: 1.00, 95\%Cl: 0.92-1.10, $\mathrm{P}=0.95$; heavy drink: HR: 1.05, 95\%Cl: 0.90-1.23, $\mathrm{P}=0.55)$.

Conclusions: In women, the risk of AF was not associated with any degree of alcohol consumption while high levels of alcohol consumption significantly increased the risk of $\mathrm{AF}$ in men.

\section{Introduction}

Atrial fibrillation (AF) is one of the most common form of clinical arrhythmia with 1-2\% prevalence in the general population [1]. In patients with $\mathrm{AF}$, effective treatment measures to control heartbeat rhythm and avoid complications exist. However, a number of adverse lifestyle factors including alcohol consumption still contribute to the increasing prevalence of AF [2].

Studies have shown that dietary components such as alcohol consumption influence cardiovascular disease morbidity and mortality [3]. The relationship between alcohol intake and AF incidence was observed when arrhythmia recurred after ablation and left atrial remodeling were done [4]. However, the relationship between AF and alcohol consumption remains controversial because a study has indicated that alcohol consumption can reduce the incidence of myocardial infarction to some extent [5]. In addition, some studies have suggested that there are no connections between AF and light-to-moderate alcohol consumption [6]. Nonetheless, alcohol consumption to some extent has been associated with an increased risk of AF in some studies [7]. A study reported that heavy alcohol consumption is associated with a higher risk of AF among men. However, this correlation was not strong among women [8].

Due to the complex association between alcohol consumption and health, we designed a dose-response meta-analysis based on cohort studies to determine the association between various levels of alcohol consumption and the risk of AF. This study also aimed at evaluating the differences between men and women in their reaction to alcohol consumption.

\section{Materials And Methods}

\subsection{Search Strategy and Eligibility Criteria}

This systematic review and meta-analysis study adhered to PRISMA guidelines (preferred reporting items for systematic reviews and meta-analyses), and followed a pre-specified protocol. A comprehensive search was done on the PubMed database, Google scholar, Web of Science, Cochrane Library, and OVID with no date restriction up to 1st June, 2020. In the search, the following key medical subject headings (MeSH) terms and Emtree terms were used: atrial fibrillation, alcohol, and ethanol. The search was restricted to randomized controlled trials (RCTs) and clinical research. Reference lists of selected studies and previous reviews were also searched for potential eligible trials. Case reports, editorials, expert opinions, review articles, editorials, guidelines, and non-English studies were excluded.

\subsection{Data Abstraction and End Points}


Two independent reviewers extracted the following data from pre-specified reports: authors, year of publication, alcohol consumption, cohort study number, number of cases of AF, and follow-up time.

Weekly alcohol intake was used to classify the level of consumption by the participants as light-moderate (1- 6 drinks/week for general people, 1-14 drinks/week for men or 1-6 drinks/week for women) and high (>14 drinks/week for general people, > 21 drinks/week for men or $>14$ drinks/week for women). In addition, $12 \mathrm{~g}$ of ethanol was converted into 1 drink.

\subsection{Statistical Analysis}

Microsoft Excel 2016, Revman 5.4 and Stata SE 15 were used to analyze the extracted data. Extraction of different alcohol intakes and their corresponding hazard ratio (HR) were obtained from each article. $I^{2}$ values of 25,50 and $75 \%$ indicated low, medium and high degree of heterogeneity respectively. A random effects model was used where analysis of the relationship between different levels of alcohol consumption and risk of AF based on the sex of the individual was represented through plotting of dose-effect curves.

\section{Results}

\subsection{Search Results}

1177 relevant literature were searched from the electronic databases when "atrial fibrillation", "alcohol", and "ethanol" key words were used. A decision on which articles to include in the study was made after reading the abstract and further examination of the full-text. Finally, 11 eligible articles were included with the analyzed data including a total of 396717 participants. $44.3 \%$ of the participants were male and the follow-up duration ranged between 4.7 to 17.6 years. The alcoholic drinks involved included beer, wine, liquor and mixed drinks. The drinks were converted into grams of ethanol on the basis of serving size, alcohol content and the density of ethanol with $12 \mathrm{~g}$ of ethanol being converted into 1 drink. The PREDIMED study [6] was not included because the extracted data could not meet the full criteria for inclusion.

The weekly alcohol intake was used to classify participants' level of consumption where for the general population, consumption of 1-6 drinks/week was classified as light-moderate consumption while consumption of $>14$ drinks/week was described as high consumption. There was no significant association between alcohol consumption and AF risk when an individual consumed 1-6 drinks per week (HR: $0.98,95 \% \mathrm{Cl}$ : $0.88-1.08, \mathrm{P}=0.63$ ). However, the risk of AF was significantly increased by consumption of more than 14 drinks per week (HR: $1.26,95 \%$ Cl: 1.16-1.37, $\mathrm{P}<0.01$ ).

\subsection{Analysis of alcohol consumption and atrial fibrillation risk according to sex}

In most cases, women tend to drink less than men. Therefore, most studies consider 1-6 drinks per week for women and 7-14 for men as light-moderate consumption while drinking > 14 drinks per week for women and $>21$ drinks per week for men is classified as heavy consumption.

Five studies reported follow-up results of the relationship between light drinking and AF in men, and six reported follow-up results of heavy drinking in men. There was no significant association between alcohol consumption and AF risk in the men who consumed between 1-14 drinks per week (HR: 1.07, 95\% Cl: 0.92-1.23, P = 0.38). However, consumption of more than 21 drinks per week significantly increased the risk of AF (HR: 1.38, 95\% Cl: $1.23-1.54, \mathrm{P}<0.01)$.

In addition, five studies reported follow-up results of the relationship between light drinking and AF in women while seven reported follow-up results of heavy drinking in women. Light- moderate or heavy alcohol consumption did not significantly increase the risk of AF in the women (light- moderate drink: HR: 1.00, 95\% Cl: 0.92-1.10, P= 0.95; heavy drink: HR: 1.05, 95\% Cl: $0.90-1.23, P=0.55)$. There was still no significant association between alcohol consumption and the risk of AF even when we defined heavy drinking among women as being more than 21 drinks per week (HR: 1.15, 95\% Cl: 0.97-1.37, P=0.11).

\subsection{Dose response relation between alcohol consumption and atrial fibrillation risk}

Page $3 / 11$ 
A dose-response curve was plotted for daily alcohol consumption dose and risk of AF on the basis of average daily alcohol consumption in different populations. A solid curve represents hazard ratios with its accompanying area representing the $95 \%$ confidence intervals. In the group of men, the curve was based on a restricted cubic spline regression model with knots at 0, 12.1, 36.1 and $102 \mathrm{~g} /$ day alcohol consumption. The curve indicated that the risk of AF increased rapidly with the consumption of more than 40 grams of alcohol per day. The curve was also based on a restricted cubic spline regression model in the women group with knots at 0, 6.4, 15.6 and $102 \mathrm{~g} /$ day alcohol consumption. Similarly, the risk of AF in women also increased rapidly with consumption of more than 40 grams of alcohol per day.

\section{Discussion}

This meta-analysis study indicates that there was no significant association between consumption of 1-6 drinks/week and AF risk. However, consumption of more than 14 drinks per week significantly increased the risk of AF. Dose response association showed an increasing nonlinear trend of AF with increased alcohol consumption. Results after the analysis of men and women groups indicated that there were sex-related differences between alcohol consumption and risk of AF. Light to moderate alcohol consumption by men did not increase the risk of AF while heavy alcohol consumption was associated with an increased risk of AF. On the other hand, light to moderate and heavy alcohol consumption by women did not increase the risk of AF indicating that there was no significant association between alcohol consumption and the risk of AF in women.

$\mathrm{AF}$ is the most common and persistent arrhythmia in humans affecting more than 33 million people worldwide. AF is often associated with multiple comorbidities and thus it poses a huge medical and economic burden. An increasing number of studies have indicated that alcohol consumption may play a role in the pathogenesis of AF [18]. A study has reported that for many individuals with AF, heavy alcohol drinking was associated with high mortality risk among men (HR: 1.51, 95\% Cl: 1.20-1.89), and high thromboembolism risk in women (HR: 1.71, 95\% Cl: 0.81-3.60) [19]. However, some studies have indicated that lowmoderate intake of alcohol is associated with cardio-protective effects and improvement in vascular health. A study reported that low-moderate alcohol consumption can prevent coronary heart disease and reduce the incidence of heart failure, atherosclerosis and peripheral vascular disease to a certain extent [20]. Therefore, long-term impacts of alcohol consumption on AF are controversial.

Our findings indicated that light-to-moderate alcohol consumption did not increase the risk of AF which is consistent with results from a study which reported that consumption of alcohol in moderation reduces the risk of heart failure and does not increase the risk of AF [17]. Moderate ethanol intake can prolong the duration of the action potential of atrial myocytes by inhibiting potassium currents $\left(\mathrm{I}_{\mathrm{KV} 1.5}\right.$ and $\left.\mathrm{I}_{\mathrm{hERG}}\right)$, thereby preventing to some extent the occurrence and persistence of AF [21]. These results can be attributed to the fact that most people in the study drank red wine which might have some cardio-protective effects. Red wine differs from other alcoholic beverages because it contains various phenolic compounds. Resveratrol, one of the phenolic compounds in red wine, has been reported to have a protective effect on the heart [22].

Acute heavy drinking during the holiday season is often accompanied by a higher incidence of $A F$, a phenomenon known as holiday heart syndrome [23]. Observational studies indicated that alcohol consumption is associated with autonomic imbalance and might lead to sympathetically triggered AF [24]. Alcohol consumption may elicit AF through vagal activation after eating and acute alcohol exposure which is able to shorten the atrial action potential and refractory period. $22-34 \%$ of paroxysmal atrial fibrillation (PAF) were reported after alcohol consumption with up to $38 \%$ PAF events being associated with vagal activity [25]. Intracellular $\mathrm{Ca}^{2+}$ signaling plays an important role in the regulation of contraction of cardiac cells. Exposure to ethanol or acetaldehyde (a byproduct of ethanol) can lead to abnormal concentrations of intracellular $\mathrm{Ca}^{2+}[26]$. Therefore, alcohol exposure activates stress kinases in atrial myocytes thereby prompting aberrant $\mathrm{Ca}^{2+}$ waves which results in increased susceptibility to atrial arrhythmias [27].

Acute drinking can result in the prolonging of intra- and inter-atrial conduction and reduction in the atrial effective refractory period, while long-term drinking can lead to cell damage and fibrosis [28]. Heavy drinkers had longer QTc intervals than nondrinkers with approximately 1.4-fold higher odds of having a prolonged QTc interval (OR: 1.43, 95\% Cl: 1.033-1.982, P<0.05) than non-drinkers [29]. A substantial proportion of the association between alcohol and AF is mediated by the left atrial

Page $4 / 11$ 
dimension ( $L A D)$. Chronic alcohol consumption can be cardiotoxic thereby leading to pathological atrial structural change. Every additional $10 \mathrm{~g}$ of alcohol consumed per day was associated with a $0.16 \mathrm{~mm}(95 \% \mathrm{Cl}, 0.10-0.21 \mathrm{~mm})$ enlargement of LAD with an estimated $24 \%(95 \% \mathrm{Cl}, 8-75)$ of the association between alcohol and $\mathrm{AF}$ risk being associated with left atrial enlargement [30]. Therefore, alcohol consumption not only induces AF but it can also cause cardiac remodeling to maintain AF.

A Women's Health Study reported that heavier consumption of two or more drinks per day was associated with a small increase in the risk of $A F$, and the risk of AF increased with the quantity of alcohol consumed [12]. In this study, the dose-response curve indicated that the risk of AF in women increased with increased alcohol consumption. However, stratified comparisons showed that there was no significant difference between alcohol consumption and AF risk even when women consumed more than 21 drinks per week. A Danish Diet, Cancer, and Health Study indicated that alcohol consumption increased risk of AF especially in men with $25 \%-46 \%$ higher risks of AF associated with intake of more than $20 \mathrm{~g} /$ day of alcohol in men but not in women [20]. The lower risk of AF in women can be attributed to the role of estrogen in speeding up alcohol metabolism [31]. However, the explanation is undermined by the conflicting views on the role of estrogen in alcohol metabolism. In most cases, there is moderate alcohol consumption by women with only few women drinking more than $36 \mathrm{~g}$ of ethanol per day. In the women group, the fit of the model was not significantly different from that of the non-linear regression model $(P=0.36)$. In addition, the doseresponse curve deviated greatly when alcohol consumption exceeded $36 \mathrm{~g} /$ day which may change the results to some extent. Therefore, evidence from more cohort studies is required to clarify the effect of alcohol consumption on the risk of AF in women.

\section{Conclusions}

The risk of AF increased with increased alcohol consumption in both men and women. There was limited association between light-moderate drinking (1-14 drinks per week for men and 1-7 drinks per week for women) and the risk of AF. On the other hand, there was a significant association between heavy drinking and risk of AF in men which was not observed in women. Therefore, increased alcohol consumption in men results in a significant increase in the likelihood of having AF.

\section{Study Limitations}

Participants in this study were enrolled in an observational cohort thus our findings may not be applicable to the general clinical population. In addition, the female population generally consumes less alcohol, and there was some bias in the stratified analysis and dose-response curves reflection of the risks of AF in heavy alcohol consumption.

\section{Declarations}

\section{Ethics approval and consent to participate}

No ethical issues involved

\section{Consent for publication}

All authors agree to be published

\section{Funding}

This study was funded by 2017 Hangzhou Health and Family Planning Technology Plan key projects (2017ZD02).

\section{Acknowledgment}

No acknowledgment

\section{Conflict of Interest:}

The authors declare no conflict of interest. 


\section{Authors' contributions}

Haifu Zhang, Qinxia Zhang, Xingwei Zhang contributed to the conception of the study; Haifu Zhang, Qinxia Zhang, Dong Yang contributed significantly to literature search and data extraction; Haifu Zhang, Qinxia Zhang performed the data analyses and wrote the manuscript; Zhao Xu, Xingwei Zhang helped perform the analysis with constructive discussions.

\section{References}

1. Dalia, A.A., et al., Anesthesiologists Guide to the 2019 AHA/ACC/HRS Focused Update for the Management of Patients With Atrial Fibrillation. J Cardiothorac Vasc Anesth, 2020. 34(7): p. 1925-1932.

2. Chung, M.K., et al., Lifestyle and Risk Factor Modification for Reduction of Atrial Fibrillation: A Scientific Statement From the American Heart Association. Circulation, 2020: p. CIR0000000000000748.

3. Shen, J., et al., Dietary factors and incident atrial fibrillation: the Framingham Heart Study. The American Journal of Clinical Nutrition, 2011. 93(2): p. 261-266.

4. Voskoboinik, A., et al., Alcohol and Atrial Fibrillation. Journal of the American College of Cardiology, 2016. 68(23): p. 25672576.

5. Smyth, A., et al., Alcohol consumption and cardiovascular disease, cancer, injury, admission to hospital, and mortality: a prospective cohort study. Lancet, 2015. 386(10007): p. 1945-54.

6. Bazal, P., et al., Mediterranean alcohol-drinking pattern, low to moderate alcohol intake and risk of atrial fibrillation in the PREDIMED study. Nutrition, Metabolism and Cardiovascular Diseases, 2019. 29(7): p. 676-683.

7. Gemes, K., et al., Does Moderate Drinking Increase the Risk of Atrial Fibrillation? The Norwegian HUNT (Nord-Trondelag Health) Study. J Am Heart Assoc, 2017. 6(10).

8. Mukamal, K.J., et al., Alcohol consumption and risk of atrial fibrillation in men and women: the Copenhagen City Heart Study. Circulation, 2005. 112(12): p. 1736-42.

9. Djousse, L., et al., Long-term alcohol consumption and the risk of atrial fibrillation in the Framingham Study. Am J Cardiol, 2004. 93(6): p. 710-3.

10. Frost, L. and P.J.A.o.I.M. Vestergaard, Alcohol and risk of atrial fibrillation or flutter: a cohort study. 2004. 164(18): p. 19931998.

11. Mukamal, K.J., et al., Alcohol consumption and risk and prognosis of atrial fibrillation among older adults: the Cardiovascular Health Study. Am Heart J, 2007. 153(2): p. 260-6.

12. Conen and D.J.J.t.J.o.t.A.M. Association, Alcohol Consumption and Risk of Incident Atrial Fibrillation in Women. 2008. 300(21): p. 2489.

13. Liang, Y., et al., Alcohol consumption and the risk of incident atrial fibrillation among people with cardiovascular disease. 2012. 184(16): p. E857-E866.

14. Sano, F., et al., Heavy alcohol consumption and risk of atrial fibrillation. The Circulatory Risk in Communities Study (CIRCS). Circ J, 2014. 78(4): p. 955-61.

15. Larsson, S.C., N. Drca, and A. Wolk, Alcohol consumption and risk of atrial fibrillation: a prospective study and dose-response meta-analysis. J Am Coll Cardiol, 2014. 64(3): p. 281-9.

16. Tolstrup, J.S., et al., Alcohol consumption and risk of atrial fibrillation: Observational and genetic estimates of association. Eur J Prev Cardiol, 2016. 23(14): p. 1514-23.

17. Di Castelnuovo, A., et al., Moderate Alcohol Consumption Is Associated With Lower Risk for Heart Failure But Not Atrial Fibrillation. JACC Heart Fail, 2017. 5(11): p. 837-844.

18. Nalliah, C.J., P. Sanders, and J.M. Kalman, The Impact of Diet and Lifestyle on Atrial Fibrillation. Curr Cardiol Rep, 2018. 20(12): p. 137.

19. Overvad, T.F., et al., Alcohol intake and prognosis of atrial fibrillation. Heart, 2013. 99(15): p. 1093-9.

20. Gardner, J.D. and A.J. Mouton, Alcohol Effects on Cardiac Function, in Comprehensive Physiology. 2015. p. 791-802. 
21. Yang, B., et al., Inhibition of potassium currents is involved in antiarrhythmic effect of moderate ethanol on atrial fibrillation. Toxicology and Applied Pharmacology, 2017. 322: p. 89-96.

22. Stephan, L.S., et al., Red Wine, Resveratrol and Atrial Fibrillation. Nutrients, 2017. 9(11).

23. Tonelo, D., R. Providencia, and L. Goncalves, Holiday heart syndrome revisited after 34 years. Arq Bras Cardiol, 2013. 101(2): p. 183-9.

24. Brunner, S., et al., Alcohol consumption, sinus tachycardia, and cardiac arrhythmias at the Munich Octoberfest: results from the Munich Beer Related Electrocardiogram Workup Study (MunichBREW). Eur Heart J, 2017. 38(27): p. 2100-2106.

25. Mandyam, M.C., et al., Alcohol and Vagal Tone as Triggers for Paroxysmal Atrial Fibrillation. The American Journal of Cardiology, 2012. 110(3): p. 364-368.

26. Rampoldi, A., et al., Cardiac Toxicity From Ethanol Exposure in Human-Induced Pluripotent Stem Cell-Derived Cardiomyocytes. Toxicol Sci, 2019. 169(1): p. 280-292.

27. Yan, J., et al., Role of Stress Kinase JNK in Binge Alcohol-Evoked Atrial Arrhythmia. J Am Coll Cardiol, 2018. 71(13): p. 14591470.

28. Qiao, Y., et al., Impact of Alcohol Consumption on Substrate Remodeling and Ablation Outcome of Paroxysmal Atrial Fibrillation. J Am Heart Assoc, 2015. 4(11).

29. Li, Z., et al., Relation of Heavy Alcohol Consumption to QTC Interval Prolongation. Am J Cardiol, 2016. 118(8): p. $1201-1206$.

30. McManus, D.D., et al., Alcohol Consumption, Left Atrial Diameter, and Atrial Fibrillation. J Am Heart Assoc, 2016. 5(9).

31. El-Mas, M.M. and A.A. Abdel-Rahman, Role of Alcohol Oxidative Metabolism in Its Cardiovascular and Autonomic Effects, in Aldehyde Dehydrogenases. 2019. p. 1-33.

\section{Table}


Table 1.

Characteristics of studies included in meta-analysis

\begin{tabular}{|c|c|c|c|c|c|c|c|c|}
\hline Author & Year & $\begin{array}{l}\text { Number of } \\
\text { participants }\end{array}$ & $\begin{array}{l}\text { Male } \\
\text { (\%) }\end{array}$ & Age & $\begin{array}{l}\text { The } \\
\text { types of } \\
\text { wine }\end{array}$ & $\begin{array}{l}\text { Alcohol } \\
\text { consumption }\end{array}$ & $\begin{array}{l}\text { Determination } \\
\text { of AF }\end{array}$ & $\begin{array}{l}\text { Follow- } \\
\text { up } \\
\text { time } \\
\text { (year) }\end{array}$ \\
\hline \multirow[t]{2}{*}{ Luc Djousse[9] } & \multirow[t]{2}{*}{2004} & \multirow[t]{2}{*}{5727} & \multirow[t]{2}{*}{51} & $\begin{array}{l}\text { Male: } \\
44.6 \pm 8.0\end{array}$ & \multirow{2}{*}{$\begin{array}{l}\text { cocktail, } \\
\text { beer, } \\
\text { wine }\end{array}$} & \multirow{2}{*}{$\begin{array}{l}0 \mathrm{~g} / \text { day; } 0.1-12.0 \\
\text { g/day; } 12.1-24 \\
\text { g/day; } 24.1-36 \\
\text { g/day; >36 g/day }\end{array}$} & \multirow[t]{2}{*}{ ECG } & \multirow[t]{2}{*}{6.4} \\
\hline & & & & $\begin{array}{l}\text { Female: } \\
47.0 \pm 7.9\end{array}$ & & & & \\
\hline \multirow[t]{2}{*}{ Lars Frost[10] } & \multirow[t]{2}{*}{2004} & \multirow[t]{2}{*}{47949} & \multirow[t]{2}{*}{47} & $\begin{array}{l}\text { Mean } \\
\text { age } 56\end{array}$ & \multirow[t]{2}{*}{$\begin{array}{l}\text { beer, } \\
\text { wine, } \\
\text { spirits }\end{array}$} & $\begin{array}{l}\text { Male: } 4.1 \pm 2.6 \mathrm{~g} / \text { day; } \\
12.1 \pm 2.1 \mathrm{~g} / \mathrm{day} ; \\
20.0 \pm 3.0 \mathrm{~g} / \mathrm{day} ; \\
36.1 \pm 4.9 \mathrm{~g} / \mathrm{day} ; \\
68.7 \pm 22.8 \mathrm{~g} / \text { day }\end{array}$ & \multirow[t]{2}{*}{ ICD codes } & \multirow[t]{2}{*}{5.7} \\
\hline & & & & & & $\begin{array}{l}\text { Female: } 1.1 \pm 0.7 \\
\text { g/day; } 4.6 \pm 1.5 \\
\text { g/day; } 9.4 \pm 1.7 \\
\text { g/day; } 15.6 \pm 2.6 \\
\text { g/day; } 38.8 \pm 14.8 \\
\text { g/day }\end{array}$ & & \\
\hline \multirow[t]{2}{*}{$\begin{array}{l}\text { Kenneth J. } \\
\text { Mukamal[8] }\end{array}$} & \multirow[t]{2}{*}{2005} & \multirow[t]{2}{*}{16415} & \multirow[t]{2}{*}{46} & $\begin{array}{l}\text { Male: } \\
55.8\end{array}$ & \multirow[t]{2}{*}{$\begin{array}{l}\text { beer, } \\
\text { wine, } \\
\text { spirits }\end{array}$} & $\begin{array}{l}<1 \text { drink/week; 1-6 } \\
\text { drinks/week; 7-13 } \\
\text { drinks/week: 14-20 }\end{array}$ & \multirow[t]{2}{*}{$\begin{array}{l}\text { hospital } \\
\text { records or } \\
\text { ECG }\end{array}$} & \multirow[t]{2}{*}{17.63} \\
\hline & & & & $\begin{array}{l}\text { Female: } \\
56.8\end{array}$ & & $\begin{array}{l}\text { drinks/week; } \geq 21 \\
\text { drinks/week(female), } \\
21-27 \\
\text { drinks/week(male); } \\
\text { 28-34 drinks/week; } \\
\text { >35 drinks/week }\end{array}$ & & \\
\hline $\begin{array}{l}\text { Kenneth J. } \\
\text { Mukamal[11] }\end{array}$ & 2007 & 5609 & 42 & $\begin{array}{l}65 \text { years } \\
\text { or older }\end{array}$ & $\begin{array}{l}\text { beer, } \\
\text { wine, } \\
\text { liquor }\end{array}$ & $\begin{array}{l}\text { None; <1drink/week; } \\
\text { 1-6drinks/week; 7-13 } \\
\text { drinks/week; >14 } \\
\text { drinks/week }\end{array}$ & $\begin{array}{l}\text { ECG or } \\
\text { hospital } \\
\text { diagnoses }\end{array}$ & 9.1 \\
\hline $\begin{array}{l}\text { David } \\
\text { Conen[12] }\end{array}$ & 2008 & 34715 & 0 & $\begin{array}{l}45 \text { years } \\
\text { or older }\end{array}$ & $\begin{array}{l}\text { beer, } \\
\text { wine, } \\
\text { liquor }\end{array}$ & $\begin{array}{l}\text { None; }<1 \text { drink/day; } \\
1-2 \text { drinks/day; } \geq 2 \\
\text { drink/day }\end{array}$ & $\begin{array}{l}\text { ECG or } \\
\text { medical } \\
\text { report } \\
\text { indicated a } \\
\text { personal } \\
\text { history of AF }\end{array}$ & 12.4 \\
\hline Jian Shen[3] & 2011 & 9640 & 44 & 62 & $\begin{array}{l}\text { beer, } \\
\text { wine, } \\
\text { liquor }\end{array}$ & $\begin{array}{l}0 \mathrm{~g} / \text { day; } 1-3 \mathrm{~g} / \text { day; } \\
3-13 \mathrm{~g} / \mathrm{day} ; 13-161 \\
\text { g/day }\end{array}$ & ECG & 4 \\
\hline \multirow[t]{2}{*}{ Yan Liang[13] } & \multirow[t]{2}{*}{2012} & \multirow[t]{2}{*}{30433} & \multirow[t]{2}{*}{70} & \multirow[t]{2}{*}{$66.4 \pm 7.2$} & \multirow[t]{2}{*}{$\begin{array}{l}\text { beer, } \\
\text { wine, } \\
\text { liquor }\end{array}$} & $\begin{array}{l}\text { Male: <1 drink/week; } \\
\text { 1-21 drinks/week; } \\
\text { >21 drinks/week }\end{array}$ & \multirow[t]{2}{*}{ ECG } & \multirow[t]{2}{*}{4.7} \\
\hline & & & & & & $\begin{array}{l}\text { Female: <1 } \\
\text { drink/week; 1-14 } \\
\text { drinks/week; >14 } \\
\text { drinks/week }\end{array}$ & & \\
\hline $\begin{array}{l}\text { Fumihiko } \\
\text { Sano[14] }\end{array}$ & 2014 & 8602 & 37 & I & $\begin{array}{l}\text { beer, } \\
\text { wine, } \\
\text { liquor }\end{array}$ & $\begin{array}{l}\text { Never; }<23 \text { g/day; } 23- \\
46 \mathrm{~g} / \text { day; } 46-69 \\
\text { g/day; >69 g/day }\end{array}$ & ICD codes & 6.4 \\
\hline $\begin{array}{l}\text { Susanna C. } \\
\text { Larsson[15] }\end{array}$ & 2014 & 79019 & 50 & 45 to 83 & $\begin{array}{l}\text { beer, } \\
\text { wine, } \\
\text { spirits }\end{array}$ & $\begin{array}{l}<1 \text { drink/week; 1-6 } \\
\text { drinks/week; 7-14 } \\
\text { drinks/week; 14-21 } \\
\text { drinks/week; } ₫ 21 \\
\text { drinks/week }\end{array}$ & ICD codes & 11 \\
\hline
\end{tabular}




\begin{tabular}{|c|c|c|c|c|c|c|c|c|}
\hline $\begin{array}{l}\text { Janne } \\
\text { Schurmann } \\
\text { Tolstrup[16] }\end{array}$ & 2016 & 88782 & 45 & $\begin{array}{l}\text { Male: } 58 \\
\text { Female: } \\
57\end{array}$ & $\begin{array}{l}\text { beer, } \\
\text { wine, } \\
\text { liquor }\end{array}$ & $\begin{array}{l}<1 \text { drink/week; 1-6 } \\
\text { drinks/week; 7-13 } \\
\text { drinks/week; 14-20 } \\
\text { drinks/week; 21-27 } \\
\text { drinks/week; } \geq 28 \\
\text { drinks/week(female), } \\
\text { 28-34 } \\
\text { drinks/week(male); } \\
\text { 28-34 drinks/week; } \\
\text { >35 drinks/week }\end{array}$ & $\begin{array}{l}\text { Hospital } \\
\text { discharge } \\
\text { codes }\end{array}$ & 7 \\
\hline $\begin{array}{l}\text { Augusto Di } \\
\text { Castelnuovo[17] }\end{array}$ & 2017 & 22824 & 48 & $55 \pm 12$ & $\begin{array}{l}\text { beer, } \\
\text { wine, } \\
\text { spirits }\end{array}$ & $\begin{array}{l}\text { Never; } 1-12 \text { g/day; } \\
13-24 \text { g/day; } 24-48 \\
\text { g/day; >48 g/day }\end{array}$ & $\begin{array}{l}\text { ECG or } \\
\text { medical } \\
\text { records }\end{array}$ & 8.2 \\
\hline $\begin{array}{l}\text { Katalin } \\
\text { Gemes[7] }\end{array}$ & 2017 & 47002 & 45 & 52.3 & $\begin{array}{l}\text { beer, } \\
\text { wine, } \\
\text { spirits }\end{array}$ & $\begin{array}{l}\text { None; } 0-3 \text { drink/day; } \\
\text { 3-7 drinks/day; } \geq 7 \\
\text { drink/day }\end{array}$ & ECG & 8 \\
\hline
\end{tabular}

AF: atrial fibrillation; ECG: electrocardiograph; ICD: international classification of diseases.

\section{Figures}

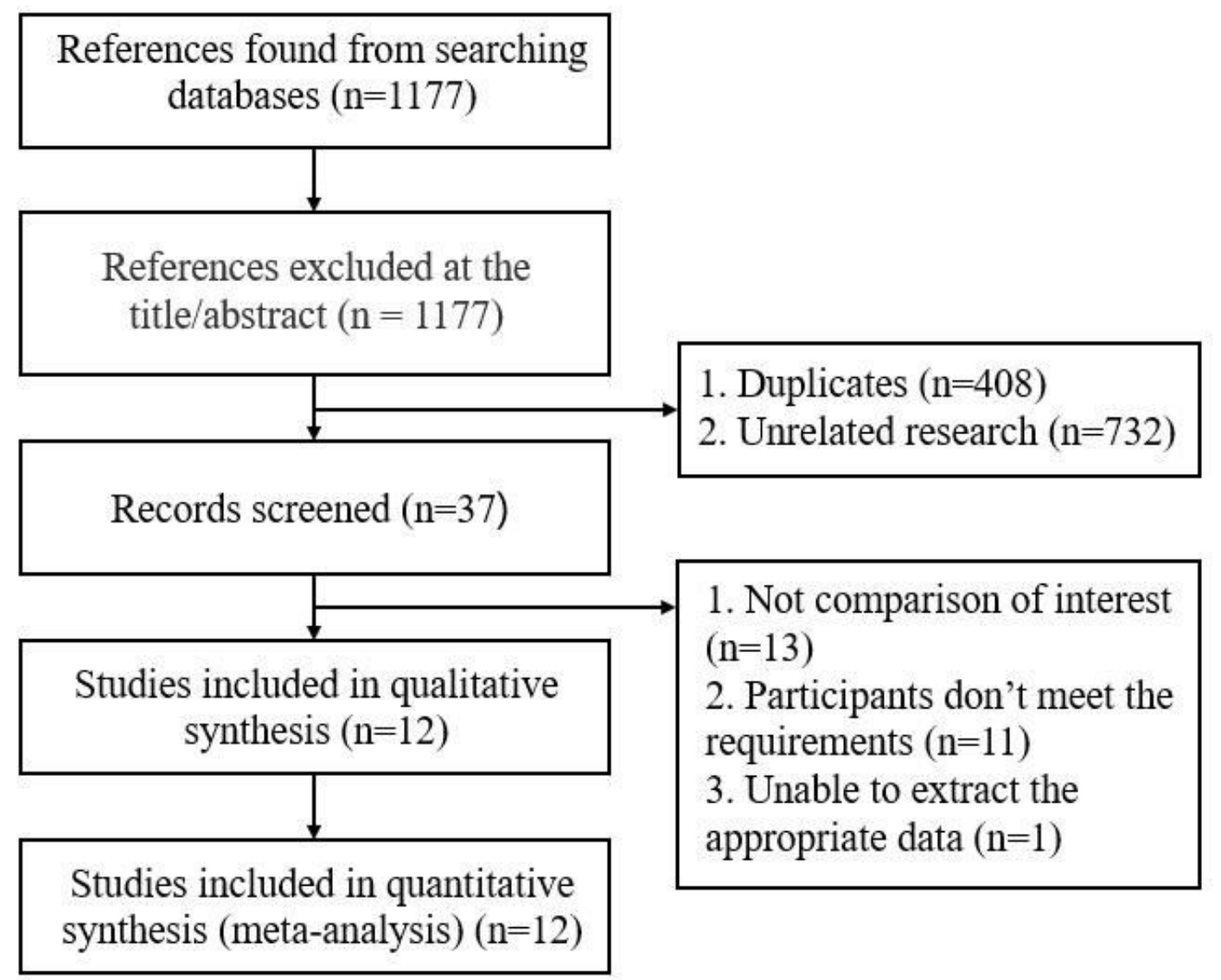

Figure 1

Figure 1 


\subsection{1 general population mildly drink}

Augusto Di Castelnuovo 2017

Jian Shen 2011

Katalin Gemes 2017

Kenneth J. Mukamal 2006

Susanna C. Larsson 2014

Subtotal $(95 \% \mathrm{Cl})$

Heterogeneity: Tau $^{2}=0.01 ; \mathrm{Chi}^{2}=6.95, \mathrm{df}=4(\mathrm{P}=0.14) ; \mathrm{I}^{2}=42 \%$

Test for overall effect: $Z=0.48(P=0.63)$

\subsection{2 general population heavy drink}

Augusto Di Castelnuovo(14-27) 2017

Augusto Di Castelnuovo(>28) 2017

Kenneth J. Mukamal(>14) 2006

Susanna C. Larsson(14-20) 2014

Susanna C. Larsson(>21) 2014

Subtotal $(\mathbf{9 5} \% \mathrm{CI})$

$\begin{array}{rrr}-0.19845095 & 0.10470291 & 17.0 \% \\ -0.1625189 & 0.16832215 & 8.3 \% \\ 0.04879012 & 0.09850235 & 18.3 \% \\ -0.05129331 & 0.09903838 & 18.2 \% \\ 0.05826885 & 0.04080805 & 38.2 \% \\ & & \mathbf{1 0 0 . 0} \%\end{array}$

SE Weight IV, Random, 95\% Cl

$0.82[0.67,1.01]$

$0.85[0.61,1.18]$

$1.05[0.87,1.27]$

$0.95[0.78,1.15]$

$1.06[0.98,1.15]$

$0.98[0.88,1.08]$

$\begin{array}{rrr}0.19885088 & 0.09574464 & 17.4 \% \\ 0.20701418 & 0.11957212 & 11.6 \% \\ 0.16551439 & 0.12024374 & 11.5 \% \\ 0.16551439 & 0.06901806 & 30.4 \% \\ 0.35767441 & 0.07082572 & 29.2 \% \\ & & \mathbf{1 0 0 . 0} \%\end{array}$

$1.22[1.01,1.47]$

$1.23[0.97,1.55]$

$1.18[0.93,1.49]$

$1.18[1.03,1.35]$

$1.43[1.24,1.64]$

$1.26[1.16,1.37]$

Heterogeneity: $\operatorname{Tau}^{2}=0.00 ; \mathrm{Chi}^{2}=4.54, \mathrm{df}=4(\mathrm{P}=0.34) ; \mathrm{I}^{2}=12 \%$

Test for overall effect: $Z=5.50(P \leq 0.00001)$

Test for subaroun differences: $\mathrm{Ch}^{2}=14.36 . \mathrm{df}=1(\mathrm{P}=0.0002) . \mathrm{I}^{2}=93.0 \%$

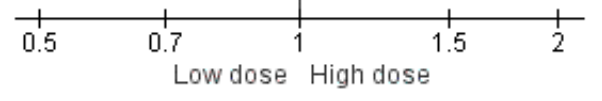

\section{Figure 2}

Figure 2

Studv or Subgroup

1.4.1 man mildly drink

Fumihiko Sano 2014

Janne Schurmann Tolstrup 2016

Kenneth J. Mukamal 2005

Lars Frost 2004

Luc Djousse 2003

Subtotal ( $95 \% \mathrm{Cl})$

Heterogeneity: $\operatorname{Tau}^{2}=0.00 ; \mathrm{Chi}^{2}=0.93, \mathrm{df}=4(\mathrm{P}=0.92) ; \mathrm{I}^{2}=0 \%$

Test for overall effect: $Z=0.87(P=0.38)$

\subsection{2 man heavy drink}

Fumihiko Sano(28-41) 2014

Fumihiko Sano(>42) 2014

Janne Schurmann Tolstrup(21-27) 2016

Janne Schurmann Tolstrup(28-34) 2016

Janne Schurmann Tolstrup(>35) 2016

Kenneth J. Mukama(28-34) 2005

Kenneth J. Mukamal(21-27) 2005

Kenneth J. Mukamal $(>35) 2005$

Lars Frost(21-27) 2004

Lars Frost $(>28) 2004$

Luc Djousse $(>21) 2003$

Yan Liang $(>21) 2012$

Subtotal (95\% Cl)

Heterogeneity: $\operatorname{Tau}^{2}=0.01 ; \mathrm{Chi}^{2}=14.04, \mathrm{df}=11(\mathrm{P}=0.23) ; \mathrm{I}^{2}=22 \%$

Test for overall effect: $Z=5.70(P \leq 0.00001)$

Test for subaroun differences: $\mathrm{Chi}^{2}=7.94 . \mathrm{df}=1(\mathrm{P}=0.005) \cdot \mathrm{I}^{2}=87.4 \%$

$\begin{array}{rrr}0.43178239 & 0.31958825 & 2.9 \% \\ 1.1969482 & 0.34863944 & 2.5 \% \\ 0.15700371 & 0.11679631 & 14.7 \% \\ 0.33647222 & 0.12796381 & 13.0 \% \\ 0.48242615 & 0.12215094 & 13.9 \% \\ 0.17395336 & 0.2161514 & 5.8 \% \\ 0.04879012 & 0.19917336 & 6.7 \% \\ 0.48242615 & 0.17126841 & 8.5 \% \\ 0.22314355 & 0.17394392 & 8.3 \% \\ 0.37843646 & 0.1694316 & 8.7 \% \\ 0.28517897 & 0.20655507 & 6.3 \% \\ 0.24686006 & 0.16693193 & 8.9 \% \\ & & 100.0 \%\end{array}$

$100.0 \%$
Hazard Ratio

SE Weight $\mathrm{N}$, Random, $95 \% \mathrm{Cl}$

$-0.05129331 \quad 0.69314718 \quad 1.1 \%$

$0.02955877 \quad 0.10850875 \quad 44.3 \%$

$\begin{array}{lll}0.17395336 & 0.13913172 & 26.9 \%\end{array}$

$0.03922068 \quad 0.18201529 \quad 15.7 \%$

$12.0 \%$

$100.0 \%$
$0.95[0.24,3.70]$

$1.03[0.83,1.27]$

$1.19[0.91,1.56]$

$1.04[0.73,1.49]$

$0.98[0.65,1.47]$

1.07 [0.92, 1.23]
$1.54[0.82,2.88]$

$3.31[1.67,6.56]$

$1.17[0.93,1.47]$

$1.40[1.09,1.80]$

$1.62[1.28,2.06]$

$1.19[0.78,1.82]$

$1.05[0.71,1.55]$

$1.62[1.16,2.27]$

$1.25[0.89,1.76]$

$1.46[1.05,2.04]$

$1.33[0.89,1.99]$

$1.28[0.92,1.78]$

$1.38[1.23,1.54]$

\section{Figure 3}

Figure 3 
Studv or Subgroup

1.2.1 woman mildly drink

David Conen 2008

Janne Schurmann Tolstrup 2016

Kenneth J. Mukamal 2005

Lars Frost 2004

Luc Djousse 2003

Subtotal $(95 \% \mathrm{Cl})$

Heterogeneity: $\mathrm{Tau}^{2}=0.00 ; \mathrm{Ch}^{2}=2.24, \mathrm{df}=4(\mathrm{P}=0.69) ; \mathrm{I}^{2}=0 \%$

Test for overall effect: $Z=0.06(P=0.95)$

\subsection{2 woman heavy drink}

David Conen(>14) 2008

Fumihiko Sano(14-27) 2014

Fumihiko Sano(>41) 2014

Janne Schurmann Tolstrup(14-20) 2016

Janne Schurmann Tolstrup(21-27) 2016

Janne Schurmann Tolstrup $(28) 2016$

Kenneth J. Mukamal(1 4-20) 2005

Kenneth J. Mukamal(>21) 2005

Lars Frost $>21) 2004$

Luc Djousse(14-20) 2003

Luc Djousse(>21) 2003

Yan Liang(>14) 2012

Subtotal $(95 \% \mathrm{Cl})$ $\begin{array}{rrr}-0.51082558 & 0.17569522 & 11.5 \%\end{array}$

$\begin{array}{lll}0.04879012 & 0.71156299 & 1.2 \%\end{array}$

$\begin{array}{lll}1.4586151 & 1.0046971 & 0.6 \%\end{array}$

$\begin{array}{lll}0 & 0.0940454 \quad 18.9 \%\end{array}$

$\begin{array}{lll}-0.07257069 & 0.14380089 & 14.1 \%\end{array}$

$0.30748471 \quad 0.16619552 \quad 12.2 \%$

$0.02955877 \quad 0.197806 \quad 10.1 \%$

$\begin{array}{lll}0.23111171 & 0.24526246 & 7.6 \%\end{array}$

$\begin{array}{lll}0.13102825 & 0.23375194 & 8.1 \%\end{array}$

$\begin{array}{lll}0.12221763 & 0.2815683 & 6.2 \%\end{array}$

$\begin{array}{lll}0.22314355 & 0.26729904 & 6.7 \%\end{array}$

$\begin{array}{lll}0.57097954 & 0.45885533 & 2.7 \%\end{array}$

$100.0 \%$
Hazard Ratio

Heterogeneity: $\mathrm{Tau}^{2}=0.03 ; \mathrm{Chi}^{2}=17.75, \mathrm{df}=11(\mathrm{P}=0.09) ; \mathrm{I}^{2}=38 \%$

Test for overall effect: $Z=0.59(P=0.55)$

Test for subaroun differences: $\mathrm{Chi}^{2}=0.23 . \mathrm{df}=1(\mathrm{P}=0.63) . \mathrm{I}^{2}=0 \%$
$0.60[0.43,0.85]$

$1.05[0.26,4.24]$

$4.30[0.60,30.81]$

$1.00[0.83,1.20]$

$0.93[0.70,1.23]$

$1.36[0.98,1.88]$

$1.03[0.70,1.52]$

$1.26[0.78,2.04]$

$1.14[0.72,1.80]$

$1.13[0.65,1.96]$

$1.25[0.74,2.11]$

$1.77[0.72,4.35]$

$1.05[0.90,1.23]$

\section{Figure 4}

Figure 4

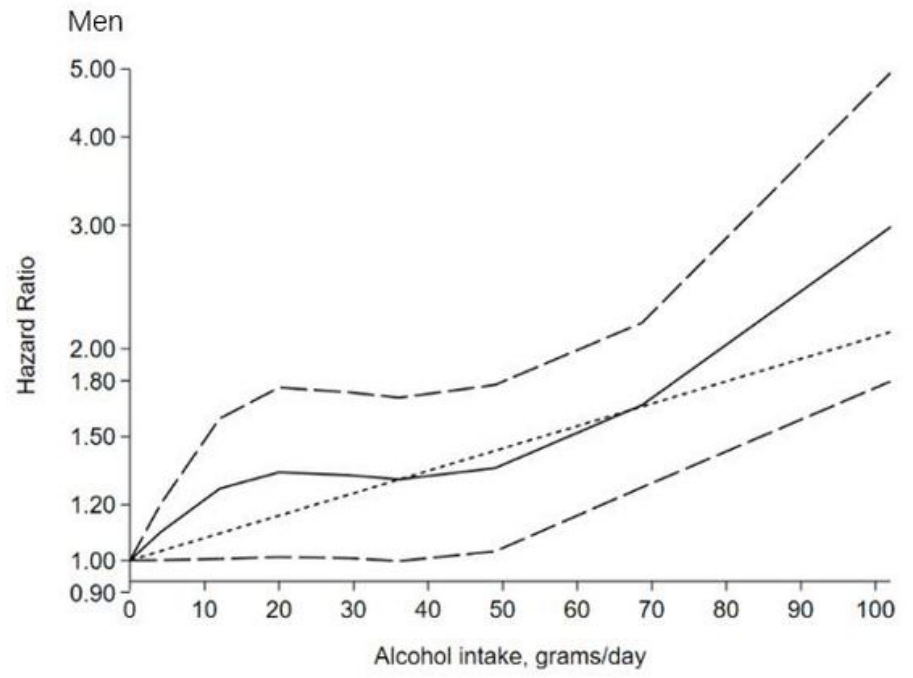

Women

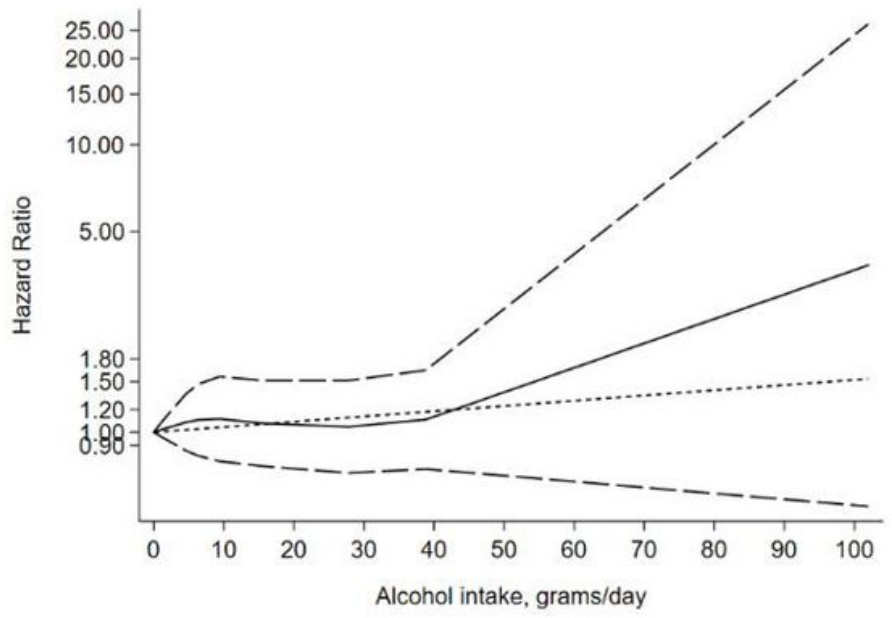

\section{Figure 5}

Figure 5 